\title{
RUBBISH OR TECHNOLOGY? A SHORT DISCUSSION
}

Lucia Hulková and Anna Wodzińska*1

\begin{abstract}
This short article presents a case of intentional use of a layer consisting of a large number of pottery sherds along with the more usual clean yellow sand in a shallow foundation trench under a fragmentary New Kingdom mudbrick wall encountered in Tell el-Retaba in the Wadi Tumilat. Various possible explanations for the use of these sherds as a part of an architectural feature are explored with the aim of drawing attention to a hitherto under-studied cultural practice in Egyptian New Kingdom settlement architecture.
\end{abstract}

Keywords: Tell el-Retaba, foundation trenching, sandbox foundation, New Kingdom, settlement architecture

Settlement archaeology has been quite neglected by Egyptologists for a long time. ${ }^{2}$ The resulting lack of a detailed understanding of depositional practices within ancient Egyptian settlements poses a serious problem for the interpretation of archaeological findings, especially in cases where the remains in question are only scarcely preserved. Since we lack textual evidence relating to everyday life of a settlement, such as waste management and the spatial distribution of specific activities or ritual practices carried out to name but a few, we rely on the well-published archaeological record for recognition and interpretation of these phenomena. When looking at the specific case of depositions of pottery sherds within settlements, one quickly realises that they are either considered in primary contexts within specific rooms, or as cultic deposits within offering pits or foundation deposits. Alternatively, they are merely considered as means of dating the specific strata

\footnotetext{
Österreichische Akademie der Wissenschaften, OREA; FWF START Project Beyond Politics: Material Culture in Second Intermediate Period Egypt and Nubia Y754 - G19.

** Institute of Archaeology at the University of Warsaw, Poland

1 The authors of this article would like to thank the organisers of the workshop, Dr. Christian Knoblauch and Dr. Vera Müller, for their helpful comments, ideas and discussion that gave rise to lots of ideas presented in this article.
}

they came from. In this short article, we would like to discuss one specific instance of deposition of pottery sherds within a settlement encountered in Tell el-Retaba (Fig. 1), and the interpretative problems and possibilities it offers beyond the aforementioned primary assemblage-rubbish-cultic paradigm.

The archaeological site of Tell el-Retaba is located in the central section of Wadi Tumilat which is a dried-out Nile tributary, forking off the delta at the height of the ancient city of Bubastis and running eastwards up to Lake Timsah. It is probably best known as a site of several military fortresses - originally believed to span the time from the First Intermediate Period until the $20^{\text {th }}$ Dynasty of the New Kingdom, excavated by W.M.F. Petrie ${ }^{3}$ at the beginning of the $20^{\text {th }}$ century. However, the history of this site is much more intricate and varied than Petrie's short excavation suggests. ${ }^{4}$

The archaeological research conducted here since 2007 by a joint Polish-Slovak mission ${ }^{5}$ not only corrected Petrie's dating of the three fortification walls, it also showed that Tell el-Retaba is far from being solely a military outpost on the way to Sinai and Syria/Palestine. The primary aim of the research in Tell el-Retaba is the examination of settlement patterns on the ancient tell and their diachronic development, in order to be able to evaluate the function of Tell el-Retaba within a broader cultural and political framework of Egyptian history. Currently, the time span covered by the excavation ranges from the Second Intermediate Period until the Late Period. By concentrating on settlement archaeology, valuable information on life and practices of inhabitants of Tell el-Reta-

\footnotetext{
See Moeller 2016, 31-38.

Petrie and Duncan 1906, 28-34.

The work of the joint Polish-Slovak mission corrected the initial dating by Petrie and showed that the earliest so far archaeologically attested settlement remains date only into the Second Intermediate Period but also that the occupation history continued until the Late Period. For further details, see RzEPKa et al. 2015, 98.
} 


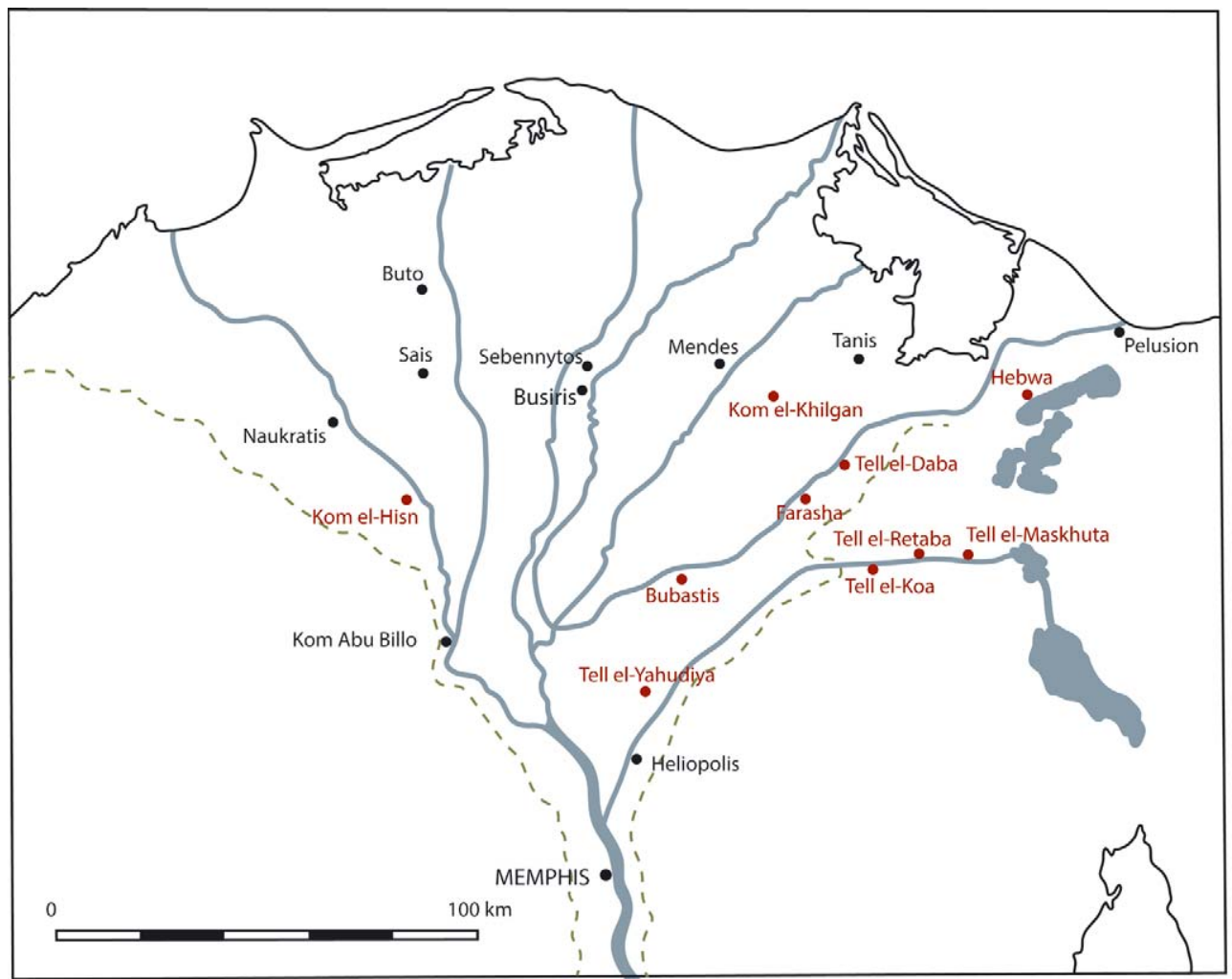

Fig. 1 Location of Tell el-Retaba in the Wadi Tumilat (Eastern Nile Delta) (Drawing: L. Hulková after BIETAK 1975, 147, Fig. 27)

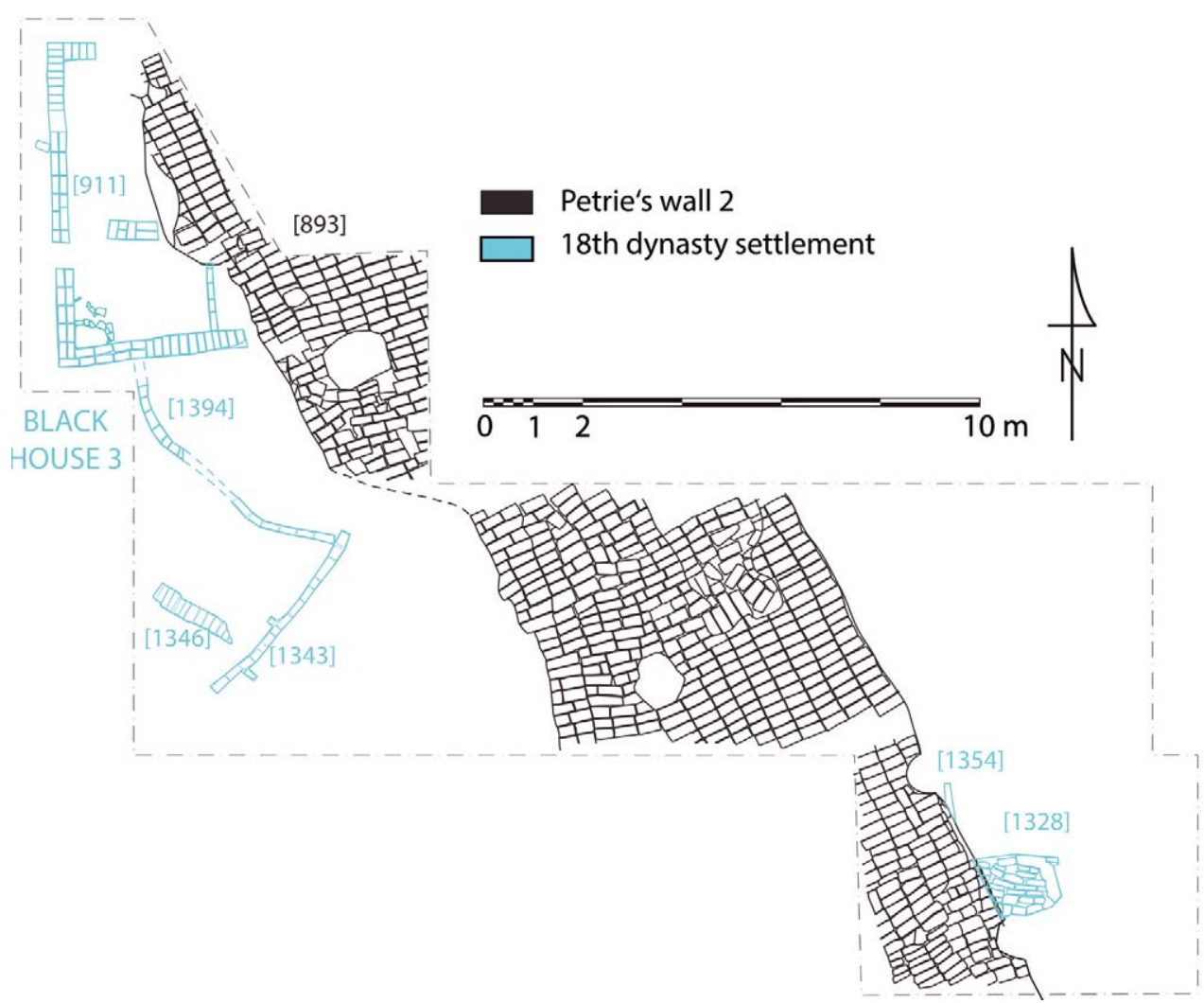

Fig. 2 Plan of southern part of the $18^{\text {th }}$ dynasty settlement in Tell el-Retaba (Spatial data: E. Stopková, Drawing: L. Hulková) 


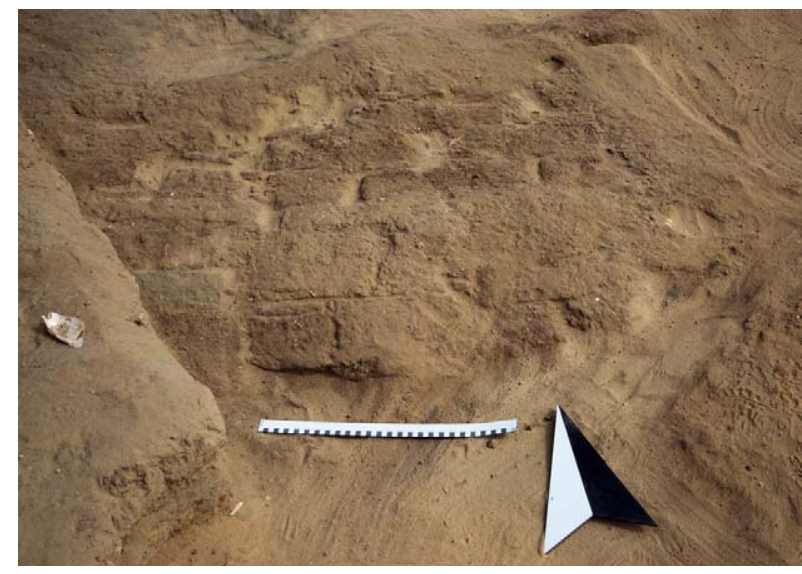

Fig. 3 Photo of the wall SU 1328 (Photo: L. Hulková)

ba during different historical periods can be gained, providing another piece of information on life in Wadi Tumilat and in ancient Egypt.

During the excavation season 2014 in Tell elRetaba, a small fragment of a poorly preserved broad wall $[1328]^{6}$ (Fig. 2) was discovered in the upper layers of the $5 \times 5 \mathrm{~m}$ large square Y110 X115, covering a part of the inner (eastern) face of the so-called Petrie's wall 2 - the later fortification wall of the $20^{\text {th }}$ Dynasty fortress - and the adjacent area to the east. The wall [1328] was dated to the reign of Hatshepsut/Thutmosis III.? It consisted of only one course of bricks set into a shallow foundation trench filled with fine yellow sand (Fig. 3). These bricks seem to be the first layer of the foundations of a wall that was c. $1.25 \mathrm{~m}$ wide. Only about $1.7 \mathrm{~m}$ of the original length of the wall are preserved. In the west it is obscured by the aforementioned fortification wall and in the east it was disturbed by a recent circular cut - similar recent cuts more or less cover the entire surface of the tell.

Judging by the thickness of the structure [1328], it is probably a part of a larger building with massive walls. However, the preserved remains are not very promising in terms of interpretation of the settlement history and allow virtually no insight into the form or the function of the building they belonged to. The preservation of remains dating into the $1^{\text {st }}$ half of the $18^{\text {th }}$ Dynasty in areas alongside the eastern face of Petrie's wall 2 uncovered so far is very bad. Other structures

\footnotetext{
For preliminary excavation reports, see RzEPKA et al. 2009; 2011; 2012; 2014; 2015.

RzEPKA et al. 2015, 109.

All the pottery analyses were conducted by Dr. Anna Wodzińska of the University of Warsaw, Institute of Archaeology.
}

dating to the reign of Hatshepsut/Thutmosis III the so called black houses ${ }^{8}$ known from squares further west and north - have far less massive walls without any recognisable foundations. Thus, lacking comparable structures within $18^{\text {th }}$ Dynasty remains in Tell el-Retaba, the incorporation of the wall [1328] into the broader settlement context remains unclear.

What is actually most interesting about the wall [1328] is its c. $10 \mathrm{~cm}$ shallow foundation trench that brought to light a surprisingly high amount of pottery sherds - 188 in total. This means that the concentration of sherds under the exposed part of the wall was c. 88 sherds $/ \mathrm{m}^{2}$. One may ask why this finding should be of special interest. Pottery sherds in the fill of a foundation trench - actually in any fill in an ancient settlement - are nothing unusual. They are found in almost every fill/deposit in Tell el-Retaba. Sherds are common settlement rubbish in Egyptian towns and villages of the New Kingdom and their abundance and variability actually make them an excellent means of dating, and thus an important backbone of chronology of any site. However, little attention beyond that is awarded to them, unless they are found within a discrete context. At Tell elRetaba we do not have any detailed information concerning the discharge of pottery vessels that were not fit for use any more. No specific waste management solution could be observed, as no dumping places for discarded vessels have been found yet. Finds from other settlement sites show that several waste management strategies were in use throughout Egypt. For example, dilapidated silos, unsuitable for their original purpose were used as dumping space for domestic refuse in Tell Edfu. ${ }^{9}$ Finds from Elephantine ${ }^{10}$ indicate that at least some part of the accumulated waste was transported outside of the city.

Despite this, settlement deposits still often contain sherds from previous periods that seem to be unintentionally mixed with other settlement rubbish, indicating that at least some broken vessels were lying around in the settlement for quite some time. Furthermore, it is also possible that through erosion of older settlement layers old sherds resur-

\footnotetext{
RZEPKA et al. 2014, 56-64, fig. 30; RZEPKA et al. 2015, $103-$ 106, fig. 2 (structure 911).

9 Moeller and Marouard. 2011, 91.

10 ArNold 2015, 158.
} 


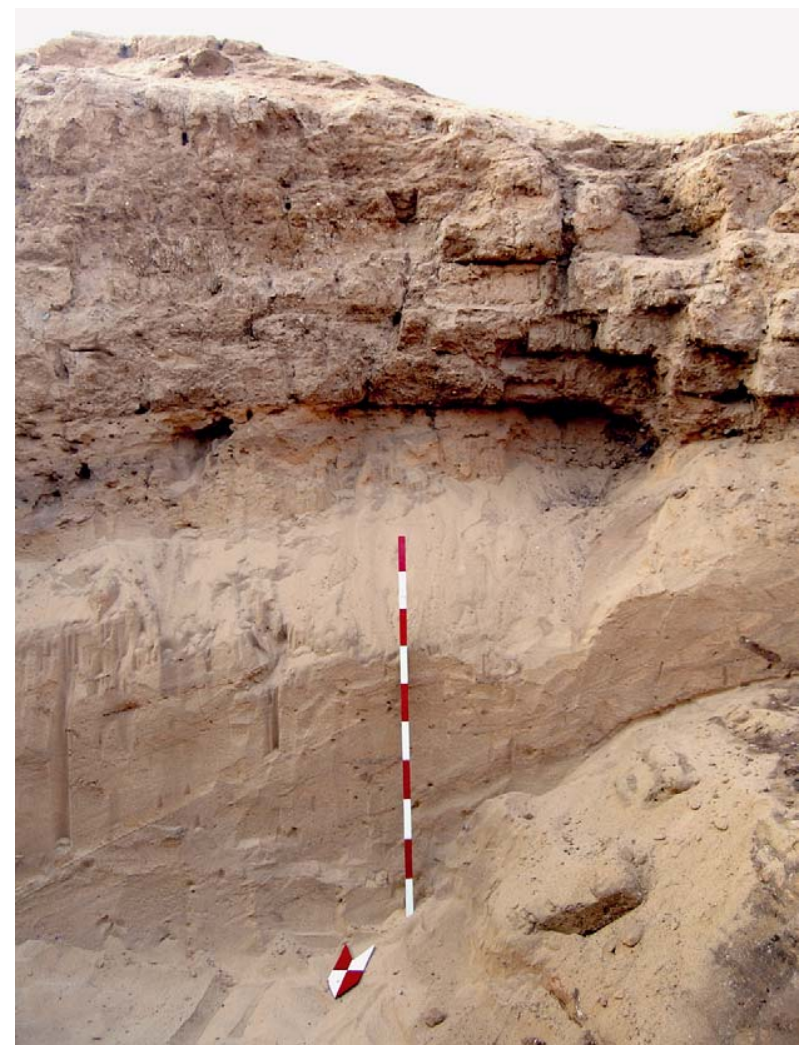

Fig. 4 Photo of the sand foundation under the Migdol gateway (L. Hudáková)

faced and became mixed with younger deposits. For example, old residual sherds with eroded edges can sometimes be found within the matrix of mudbricks. However, occasional finds of tools and implements made of pottery sherds indicate that (at least some) sherds were considered a useful resource. In these cases, the reused sherds may be considerably older than the final context in which they were deposited. In Tell el-Retaba a sherd of a Second Intermediate Period vessel was found reused in New Kingdom layers.

Keeping this in mind, it is not surprising that sherds are found in material filling the foundation trenches of ancient Egyptian buildings. They came in the course of the re-deposition of discarded material. As most buildings of later settlement phases are built upon older settlement layers, material from these layers is transported to the surface whenever a pit is dug. It is also probable that the material dug out of a foundation trench was either used to fill (at least part of) the foundation trench after the foundation wall was constructed. A good example of unintentional deposi- tion of residual sherds in Tell el-Retaba are the few pottery sherds found scattered through the sand filling of the foundation for the mudbrick platform built underneath the northern tower of the Migdol gateway (Fig. 4) and the adjoining fortification wall (Petrie's wall 2). The analysis of sherds recovered from here showed a mixed assortment of small, not adjoining sherds ranging from the reign of Hatshepsut/Thutmosis III of the $18^{\text {th }}$ Dynasty up to Ramses II of the $19^{\text {th }}$ Dynasty. No specific spatial distribution of these sherds within the sandy fill was noted. The sherds were mixed throughout the sand, without any recognisable intention or relation to the foundation trench or brickwork of the platform. Therefore, it can be supposed that these sherds were already in the sand before it was used to fill the foundations of the Midgol tower of Ramses III.

In the case of the foundation of wall [1328] it was the comparably large amount of pottery sherds as well as the fact that they seemed to be more or less confined to the area directly under the mudbricks and not being present in the fill to the sides of the wall, that suggested to us that we were dealing with an intentional deposition of selected materials, rather than a random accumulation or a re-deposition of rubbish as fill.

The pottery assemblage in SU [1328] consisted of 188 very fragmented sherds with occasional larger fragments. Within the material, 29 sherds can be classified as diagnostic pieces, i.e. fragments of rims, bases or handles. Most of them were bowls, 25 in number, only four closed forms could be recognised, including three fragments of amphorae and possibly one rim of a stand but of very small size (Fig. 5:3). Six of these diagnostic pieces were drawn to illustrate the characteristic forms (Fig. 5:1-6).

Fragments of amphorae (Fig. 5:1-2) made of marl D fabric can be well associated with the early $18^{\text {th }}$ Dynasty. ${ }^{11}$ The same holds true for bowls made of Nile B2 fabric shown in Fig. 5:4 $4^{12}$ and Fig. $5: 5^{13}$ found in deposits filling the rooms of Black House 1 in the northern part of the tell. ${ }^{14} \mathrm{~A}$ carinated bowl made of Nile B2 fabric and covered with creamy slip was found as well (Fig. 5:6). Its external surface was painted: two horizontal red bands and one wavy strip between them. Such bowls are well known in Tell el-Retaba also from

\footnotetext{
Hope 1989, fig. 1, category 1a; Aston 2005, 188, fig. 6c.

12 WoDZIŃSKA in RZEPKA et al. 2014, fig. 105.11.
} 


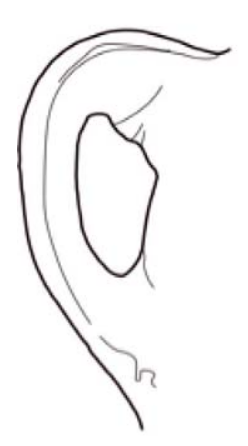

$1328-14886$

1328-14885

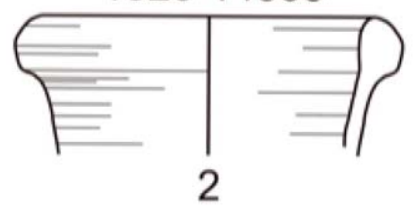

$0 \quad 5 \mathrm{~cm}$

1

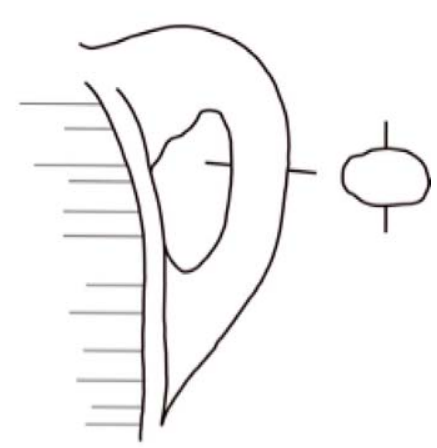

1328-14898

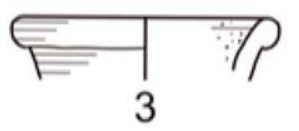

$1328-14890$
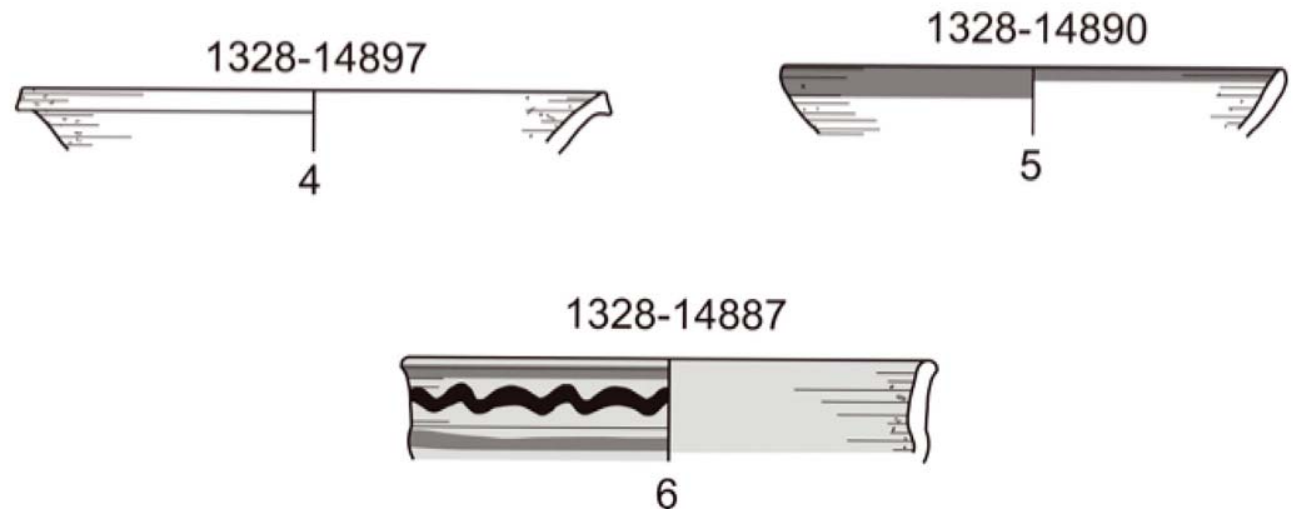

Fig. 5 Pottery from under the wall SU 1328 (Drawing: A. Wodzińska)

early $18^{\text {th }}$ Dynasty contexts..$^{15}$ Comparative material from Tell el-Retaba shows that similar vessel forms were in use in the so-called Black Houses. The fact that all diagnostic fragments fit well within the same chronologic range supports the assumption that the sherds were deposited intentionally. However, since the early $18^{\text {th }}$ Dynasty covers a considerable time span, this fact cannot be seen as definite proof.

The only thematised intentional deposition of pottery in connection with foundation events in Egyptian archaeology are so-called foundation deposits. ${ }^{16}$ From what we can reconstruct from ancient texts and archaeological remains, foundation deposits were a part of rituals connected with the erection of a new building, mostly a temple, a palace as well as royal and sometimes even private

5 WodZIŃSKa in RzEPKA et al. 2012, fig. 54.

16 Weinstein 1973; Shaw and Nicholson 2010, 141-143. tombs of officials of high rank. ${ }^{17}$ These deposits were usually placed at important points of the building, such as corners or entrances. This religious practice seems to have been very popular during the New Kingdom and, in fact, at Tell elRetaba, W.M.F. Petrie found one such deposit under the south-eastern corner of the defence walls of the fortress of Ramses III. ${ }^{18}$ Apart from pottery bowls, this deposit also contained faience amulets and animal bones.

We may ask if the pottery sherds found under the wall [1328] might indicate a similar practice. It cannot be said if this wall once belonged to an important building, but it is the broadest wall fragment from this period found in Tell el-Retaba until now, which would be consistent with such an interpretation. On the other hand, there is no

\footnotetext{
17 See SAKR 2005, 349-355.

18 Petrie and Duncan 1906, 30.
} 
account of a foundation deposit known to the authors consisting of sherds scattered loosely in a foundation trench, without any further offerings, such as animal bones or model tools, to name but a few. The fact that the sherds, partly very small ones, coming from various types of vessels (no complete shapes could be reconstructed, see below) found in the foundation trench were not concentrated in one place and the lack of other offerings renders the interpretation of these sherds as a ritual foundation deposit, at least as we currently understand this phenomenon in Egyptology, improbable and another explanation should be sought.

A note by W.M.F. Petrie, mourning the rapid rate of denudation of ancient Egyptian sites, may shed some new light onto the matter. When describing the sebakheen activity in Tell elYahudiya, Petrie observed: “... bricks have all been elaborately cut away to put on the land around, the sand is being carted away every day to use in building and even the very potsherds are collected to place in foundation of houses. ${ }^{19}$ " Unfortunately, he does not elaborate on what the function of the pottery sherds in the foundation is. However, taking this into consideration, it is possible that the builders of the wall [1328] were also aware of the possibility of using pottery sherds to substitute a certain amount of the sand in the foundation trench. The use of sand-box foundations ${ }^{20}$ in Egypt is well attested from the New Kingdom. Clean yellow sand in the foundation is usually regarded as a ritual reconstruction of the sacred mound of Heliopolis. While this might have been one of the reasons, it is also true that sandy filling undeniably has technological advantages: it can be levelled out and easily compacted, and it protects the foundations from ground water. By substituting part of the sand by pottery sherds, some material could be saved, without changing the relevant technical parameters. ${ }^{21}$ It is questionable if econo- my really was the reason behind the deposition of the sherds in the foundation trench of wall [1328]. Sand most probably was not a scarce resource in Wadi Tumilat. Even though the natural soil under the part of the settlement under discussion is composed of fine alluvial gravel, sandy deposits are reported by excavators in Tell el-Maskhuta ${ }^{22}$ some $15 \mathrm{~km}$ further east. Furthermore, examples of larger building projects from different sites show that the transport of large amounts of building material was common in Ancient Egypt. Thus, we cannot securely rule out the possibility that besides their technical function the sherds also played some religious/cultic role. Since no parallels for such depositions are known to the authors, it is not clear if this practice was used in ancient Egypt on a larger scale, or if the case from Tell el-Retaba is just a singular event. Future archaeological work providing more parallels is needed to better understand such a phenomenon.

It is of course difficult to answer the question on such a scanty evidence. It is still possible that the sherds ended up as the top layer covering the sand fill of the foundation trench under the wall [1328] only by chance. The aim of this article was to point out a hitherto under-studied cultural practice in Egyptian New Kingdom settlements that the authors consider to be potentially significant, and to start a discussion on the matter. Further careful observations are needed to clarify if there are more instances of intentional use and deposition of sherds in the building process for other than purely religious purposes. We certainly need to be open to the possibility of a much broader spectrum of depositional practices than intentional ritual depositions on the one hand or completely unintentional discard as rubbish on the other. Under careful observation of the context, new possibilities for use and reuse of supposed "waste" may be found.
Petrie and Duncan 1906, 3.

JOSEPHSON 2005, 404-405.
21 Personal communication with the Construction Engineer M. Černý, member of Tell el-Retaba excavation team.

22 Holladay 1982, 44. 


\section{Bibliography}

ARnold, F.

2015 Clean and Unclean Space: Domestic Waste Management at Elephantine, 151-168, in: M. MüLlER (ed.), Household Studies in Complex Societies: (Micro) Archaeological and Textual Approaches, OIS 10, Chicago.

Aston, D.A.

2005 Amphorae in New Kingdom Egypt, Ä\&L 14, 175-214. BiETAK, M.

1975 Tell el-Dab'a II, UZK 1, Vienna.

Holladay, J.S.

1982 Tell el-Maskhuta: Preliminary Report on the Wadi Tumilat Project 1978-79, Cities of the Delta 3, Malibu.

Hope, C.A.

1989 Amphorae of the New Kingdom, 87-126, in: C.A. Hope (ed.), Pottery of the Egyptian New Kingdom: Three Studies, Burwood.

JOSEPHSON, J.A.

2005 The Use of "Sand-box" Foundations in Ancient Egypt, 401-406, in: P. JÁnosI (ed.), Structure and Significance, Thoughts on Ancient Egyptian Architecture (Festschrift für Dieter Arnold), UZK 25, Vienna.

Moeller, N.

2016 The Archaeology of Urbanism in Ancient Egypt. From the Predynastic Period to the End of the Middle Kingdom, Cambridge.

Moeller, N. and Marouard, G. with a contribution by Ayers, $\mathrm{N}$.

2011 Discussion of Late Middle Kingdom and Early Second Intermediate Period History and Chronology with Relation to the Khayan Sealing from Tell Edfu, Ä\&L 21, 87-122.
Petrie, W.M.F. and Duncan, J.G.

1906 Hyksos and Israelite cities, British School of Archaeology in Egypt and Egyptian research account, twelfth year, London.

Rzepka, S., Hudec, J., Jarmużek, Ł., Dubcová, V., Hulková, L., Odler, M., Wodzińska, A., Trzciński, J., ŠefČÁková, A., SóJka, P., Fulajtár, E., Černý, M. and Tirpák, J.

2015 From Hyksos Settlers to Ottoman Pipe Smokers. Tell el-Retaba 2014, Ä\&L 25, 97-166.

Rzepka, S., Hudec, J., Wodzińska, A., Jarmużek, Ł., Hulková, L., Dubcová, V., Piorun, M. and Šefčáková, A.

2014 Tell el-Retaba from the Second Intermediate Period till the Late Period: Results of the Polish-Slovak Archaeological Mission, Seasons 2011-2012, Ä\&L 24, 39-120.

Rzepka, S., Nour el-Din, M., Wodzińska, A. and Jarmużek, $Ł$.

2012 Egyptian Mission Rescue Excavations in Tell el-Retaba. Part I: New Kingdom Remains, Ä\&L 22, 253-287.

Rzepka, S., Wodzińska, A., Hudec, J. and Herbich, T.

2009 Tell el-Retaba 2007-2008, Ä\&L 19, 241-280.

Rzepka, S.,Wodzińska, A., Malleson, C., Hudec, J., Jarmużek, Ł., Misiewicz, K., MaŁkowski, W. and Bogacki, M.

2011 New Kingdom and the Third Intermediate Period in Tell el-Retaba: Results of the Polish-Slovak Archaeological Mission, Seasons 2009-2010, Ä\&L 21, 129184.

SAKR, F.M.

2005 New Foundation Deposits of Kom el-Hisn, Studien zur Altägyptischen Kultur 33, 349-355.

Shaw, I. and Nicholson, P.

2010 Lexikon des alten Ägypten, Stuttgart.

WEINSTEIn, J.B.

1973 Foundation Deposits in Ancient Egypt, PhD Thesis, University of Pennsylvania. 
